\title{
THE GLUCOSE METABOLISM OF PATIENTS WITH MALIGNANT DISEASE AND OF NORMAL SUBJECTS AS STUDIED BY MEANS OF AN INTRAVENOUS GLUCOSE TOLERANCE TEST 1,2
}

\author{
By PAUL A. MARKS AND JONATHAN S. BISHOP 3 \\ (From the Medical Services of The Francis Delafield Hospital and The Presbyterian Hospital, \\ Department of Medicine, Columbia University College of Physicians \\ and Surgeons, New York City, N. Y.)
}

(Submitted for publication September 5, 1956; accepted October 4, 1956)

Since the observations of Freund (2) in 1885 of spontaneous hyperglycemia in patients with malignant disease, there has been speculation that an alteration in glucose metabolism is associated with neoplasia in man (3-18). There have been, however, relatively few studies designed specifically to test this possibility. Rohdenburg, Bernhard, and Krehbiel (5) and Edwards (6), with the advent of the oral glucose tolerance test, reported that a decrease in carbohydrate tolerance was a uniform finding in patients with cancer. Subsequent studies $(7-18)$ did not confirm these reports, though several workers have found a high incidence of an abnormal glucose tolerance test in subjects with various types of neoplasms. These observations have been inconclusive with regard to establishing a relationship between the presence of uncomplicated neoplastic disease and an altered carbohydrate metabolism. A primary reason for the inconclusive nature of these studies is their lack of control of various factors known to decrease glucose tolerance. Certain of these factors, e.g., inadequate dietary intake, fever, infection, hepatic dysfunction and prolonged bed rest, are frequently present in patients with malignant disease.

This study was undertaken in a group of carefully selected patients with chronic leukemia, lymphoma, and clinically early epithelial neoplasms, and subjects without cancer, in an effort to determine whether a defect in glucose metabolism is associated with malignant tumors. It was found that, as a group, the patients with neoplastic dis-

\footnotetext{
1 A portion of the present data has been published previously in abstract form (1).

2 This work was supported in part by a grant from The National Cancer Institute, U. S. Public Health Service.

3 Fellow of the American Cancer Society.
}

ease had a significant decrease in the rate of disappearance of glucose from the blood following the intravenous injection of glucose. Carbohydrate metabolism was evaluated further in these subjects by calculation of the net rate of disappearance of glucose from the blood and the volume of distribution of glucose and by determination of the changes in serum inorganic phosphate and potassium concentrations during the glucose tolerance tests.

\section{METHODS}

\section{Subjects studied}

The control group consisted of 19 individuals without neoplastic disease, 7 males and 12 females, ranging in age from 29 to 65 years. The neoplastic group included 36 individuals, 14 males and 22 females, ranging in age from 36 to 70 years. There was no significant difference between the control and neoplastic groups with respect to age or body weight. Subjects 20 through 33 had clinically localized carcinoma, which was in all instances considered amenable to curative therapy. These individuals had no systemic symptoms. Carcinoma was suspected on the basis of a finding of a lump in the breast on physical examination, a positive Papanicoloau smear on routine cervical examination, or an abnormal shadow on routine chest $x$-ray. Subjects 34 through 54 had lymphoma or chronic leukemia. The diagnosis in each individual was established histologically (Tables I and II). All subjects were studied preoperatively, or prior to chemotherapy or radiotherapy.

The criteria for selection of individuals for study in both the control and patient group included: 1) no family history of diabetes mellitus, 2) full ambulation, 3) no weight change for at least six months prior to the study, 4) no obesity, 5) no evidence or history of any disorder known to affect carbohydrate metabolism, 6) no fever, 7) normal serum concentrations of sodium, potassium, chloride, carbon dioxide, non-protein nitrogen, alkaline phosphatase, cholesterol and cholesterol ester, and a normal cephalin flocculation, and 8) an adequate dietary intake. 
TABLE I

Intravenous glucose tolerance test in control subjects

\begin{tabular}{|c|c|c|c|c|c|c|c|c|c|c|c|c|c|c|c|}
\hline \multirow{2}{*}{$\begin{array}{l}\text { Subject } \\
\text { No.* }\end{array}$} & \multirow{2}{*}{$\begin{array}{l}\text { Fasting } \\
\text { glucoset }\end{array}$} & \multicolumn{8}{|c|}{$\begin{array}{c}\text { Glucose concentration (mgm. \%) } \\
\text { (Time in minules) }\end{array}$} & \multicolumn{2}{|c|}{$\begin{array}{l}\text { Disappearance } \\
\text { rate constant } \\
\text { (\%/min.) }\end{array}$} & \multicolumn{2}{|c|}{$\begin{array}{c}\text { Mean glucose } \\
\text { concentration } \ddagger \\
(m g m . \%)\end{array}$} & \multicolumn{2}{|c|}{$\begin{array}{c}\text { Net glucose } \\
\text { disappearancet } \\
\text { (mgm. \%/min.) }\end{array}$} \\
\hline & & 8 & 16 & 24 & 32 & 40 & 48 & 56 & 64 & Total & Increment & Total & Increment & Total & Increment \\
\hline $\begin{array}{r}1 \\
2 \\
3 \\
4 \\
5 \\
6 \\
7 \\
8 \\
9 \\
10 \\
11 \\
12 \\
13 \\
14 \\
15 \\
16 \\
17 \\
18 \\
19\end{array}$ & $\begin{array}{r}79 \\
64 \\
88 \\
80 \\
100-98 \\
86-88 \\
75-76 \\
68-66 \\
88-85 \\
92-90 \\
83-83 \\
89-94 \\
82-87 \\
73-72 \\
83-81 \\
81-70 \\
92-88 \\
78-82 \\
84-85\end{array}$ & $\begin{array}{l}266 \\
219 \\
288 \\
304 \\
263 \\
284 \\
198 \\
250 \\
188 \\
275 \\
175 \\
264 \\
188 \\
180 \\
231 \\
240 \\
258 \\
210 \\
250\end{array}$ & $\begin{array}{l}231 \\
192 \\
240 \\
244 \\
222 \\
198 \\
191 \\
216 \\
176 \\
243 \\
156 \\
208 \\
156 \\
172 \\
192 \\
230 \\
212 \\
186 \\
168\end{array}$ & $\begin{array}{l}200 \\
185 \\
188 \\
200 \\
202 \\
135 \\
164 \\
175 \\
152 \\
198 \\
138 \\
176 \\
122 \\
155 \\
147 \\
193 \\
188 \\
160 \\
142\end{array}$ & $\begin{array}{l}175 \\
153 \\
164 \\
176 \\
179 \\
110 \\
144 \\
148 \\
131 \\
176 \\
128 \\
145 \\
104 \\
141 \\
123 \\
174 \\
175 \\
145 \\
115\end{array}$ & $\begin{array}{r}156 \\
115 \\
124 \\
148 \\
164 \\
87 \\
120 \\
125 \\
122 \\
161 \\
117 \\
121 \\
92 \\
128 \\
108 \\
158 \\
160 \\
131 \\
104\end{array}$ & $\begin{array}{r}141 \\
96 \\
92 \\
120 \\
151 \\
64 \\
106 \\
109 \\
108 \\
147 \\
110 \\
110 \\
92 \\
117 \\
97 \\
137 \\
140 \\
114 \\
90\end{array}$ & $\begin{array}{r}129 \\
87 \\
76 \\
92 \\
140 \\
60 \\
96 \\
98 \\
104 \\
134 \\
95 \\
92 \\
90 \\
110 \\
78 \\
134 \\
132 \\
94 \\
87\end{array}$ & $\begin{array}{r}119 \\
80 \\
73 \\
86 \\
125 \\
59 \\
89 \\
77 \\
99 \\
122 \\
83 \\
86 \\
87 \\
102 \\
70 \\
110 \\
111 \\
80 \\
82\end{array}$ & $\begin{array}{l}1.51 \\
2.30 \\
2.89 \\
2.20 \\
1.31 \\
3.47 \\
1.78 \\
2.30 \\
1.56 \\
1.51 \\
1.33 \\
2.16 \\
2.01 \\
1.31 \\
2.08 \\
1.59 \\
1.61 \\
1.58 \\
3.15\end{array}$ & $\begin{array}{l}2.81 \\
4.62 \\
4.36 \\
3.75 \\
3.10 \\
7.96 \\
3.22 \\
4.08 \\
3.96 \\
3.15 \\
3.22 \\
5.10 \\
6.42 \\
2.78 \\
6.30 \\
2.90 \\
2.78 \\
3.15 \\
6.03\end{array}$ & $\begin{array}{l}235 \\
223 \\
180 \\
209 \\
200 \\
132 \\
158 \\
183 \\
206 \\
209 \\
160 \\
185 \\
143 \\
151 \\
208 \\
199 \\
187 \\
165 \\
142\end{array}$ & $\begin{array}{r}139 \\
112 \\
111 \\
120 \\
89 \\
66 \\
80 \\
103 \\
81 \\
105 \\
62 \\
76 \\
43 \\
74 \\
67 \\
113 \\
104 \\
80 \\
73\end{array}$ & $\begin{array}{l}3.68 \\
5.12 \\
5.20 \\
4.60 \\
2.62 \\
4.58 \\
2.81 \\
4.21 \\
3.21 \\
3.16 \\
2.12 \\
5.00 \\
3.73 \\
2.36 \\
4.83 \\
3.16 \\
2.98 \\
2.74 \\
4.88\end{array}$ & $\begin{array}{l}3.91 \\
5.19 \\
4.85 \\
4.50 \\
2.76 \\
5.25 \\
2.58 \\
4.20 \\
3.21 \\
3.31 \\
2.00 \\
3.88 \\
3.58 \\
2.49 \\
4.52 \\
3.28 \\
2.86 \\
2.62 \\
4.03\end{array}$ \\
\hline $\begin{array}{l}\text { Averag } \\
\text { S.D. }\end{array}$ & $\begin{array}{r}83 \\
8\end{array}$ & $\begin{array}{r}238 \\
38\end{array}$ & $\begin{array}{r}202 \\
28\end{array}$ & $\begin{array}{r}164 \\
26\end{array}$ & $\begin{array}{r}148 \\
23\end{array}$ & $\begin{array}{r}129 \\
23\end{array}$ & $\begin{array}{r}113 \\
22\end{array}$ & $\begin{array}{r}101 \\
22\end{array}$ & $\begin{array}{l}92 \\
18\end{array}$ & $\begin{array}{r}1.97 \\
.62\end{array}$ & $\begin{array}{l}4.20 \\
1.52\end{array}$ & $\begin{array}{r}180 \\
29\end{array}$ & $\begin{array}{l}89 \\
24\end{array}$ & $\begin{array}{l}3.74 \\
1.04\end{array}$ & $\begin{array}{l}3.68 \\
0.93\end{array}$ \\
\hline
\end{tabular}

* Diagnoses: Cases 1-5, 9, 11-13, 16-19: Volunteers. Cases 6, 7, 10, 14, 15: Fibroadenoma of breast. Case 8: Cervical erosion.

† Where single value for fasting glucose is given, only one fasting blood sample was obtained.

$\ddagger$ Refer to text for definition of these terms and methods of calculating their values.

\section{Procedures}

All subjects were placed on a diet containing at least 225 grams of carbohydrate and 2400 calories daily for two weeks prior to study. Each individual, having fasted overnight for 14 hours, was kept completely at rest in an air conditioned room (temperature 78 to $81^{\circ} \mathrm{F}$ ) for onehalf hour prior to and during the test. An indwelling Cournand-type needle was placed in an antecubital vein. After two fasting blood samples had been obtained over a period of approximately 20 minutes, a 30 per cent glucose solution in distilled water was injected into another vein. In control subjects, 1 through 11 , and patients 20 through 27 , and 34 through 42 , twenty-five grams of glucose was administered from a syringe over a four-minute period. In all other individuals, the glucose was administered using a Bowman constant infusion pump over a three to five-minute period. This permitted a more accurate determination of the amount of glucose delivered (Table VI).

Venous blood specimens were withdrawn without stasis into heparinized syringes at eight minutes following the start of the glucose injection and subsequently every eight minutes for 64 minutes. Glucose concentration and, when performed, serum inorganic phosphate and serum potassium concentrations were determined in duplicate on each blood sample. The blood specimens were immediately iced and protein-free filtrates for the glucose analyses were promptly prepared at the bedside. Urine was collected during the 75 minutes following the injection of glucose for the determination of urinary glucose excretion during the test.

Ten patients had 2 or 3 repeat glucose tolerance tests performed (Table III). Six of these subjects were maintained on a constant carbohydrate and caloric intake on the metabolic ward during the interval between the studies. The remaining four individuals followed the prescribed diet on an outpatient basis during the period of observation.

Glucose was determined in duplicate by the Nelson modification of the Somogyi method $(19,20)$. Serum inorganic phosphorus determinations were made according to the method of Taussky and Shorr (21). Serum potassiums were determined using a flame photometer with an internal standard.

\section{Analysis of glucose tolerance curves}

Methods of analysis of the rapid intravenous glucose tolerance test have varied. In the present study, each glucose tolerance curve was graphically evaluated both by the method suggested by Conard, Franckson, Bastenie, Kestens, and Kovacs (22) and by the technique employed by Amatuzio, Stutzman, Vanderbilt, and Nesbitt (23). These two methods were chosen because (a) they provide methods which facilitate analyzing the glucose tolerance curve in terms of a single constant, (b) a large amount of normal data is available in the literature for these techniques, and (c) in the present study, by means of statistical analyses which will be presented below, 
TABLE II

Intravenous glucose tolerance tests in patients with neoplastic disease

\begin{tabular}{|c|c|c|c|c|c|c|c|c|c|c|c|c|c|c|c|}
\hline \multirow{2}{*}{$\begin{array}{l}\text { Subject } \\
\text { No.* }\end{array}$} & \multirow{2}{*}{$\begin{array}{l}\text { Fasting } \\
\text { glucose }\end{array}$} & \multicolumn{8}{|c|}{$\begin{array}{c}\text { Glucose concentration (mgm. \%) } \\
\text { (Time in minuies) }\end{array}$} & \multicolumn{2}{|c|}{$\begin{array}{l}\text { Disappearance } \\
\text { rate constant } \\
(\% / \text { min. })\end{array}$} & \multicolumn{2}{|c|}{$\begin{array}{c}\text { Mean glucose } \\
\text { concentration } \ddagger \\
(m g m . \%)\end{array}$} & \multicolumn{2}{|c|}{$\begin{array}{c}\text { Net glucose } \\
\text { disappearancet } \\
\text { (mgm. \%/min.) }\end{array}$} \\
\hline & & 8 & 16 & 24 & 32 & 40 & 48 & 56 & 64 & Total & Increment & Total & Increment & Total & Increment \\
\hline $\begin{array}{l}20 \\
21 \\
22 \\
23 \\
24 \\
25 \\
26 \\
27 \\
28 \\
29 \\
30 \\
31 \\
32 \\
33 \\
34 \\
35 \\
36 \\
37 \\
38 \\
39 \\
40 \\
41 \\
42 \\
43 \\
44 \\
45 \\
46 \\
47 \\
48 \\
49 \\
50 \\
51 \\
52 \\
53 \\
54 \\
55\end{array}$ & $\begin{array}{r}84 \\
104 \\
90 \\
93 \\
90-94 \\
82 \\
101-98 \\
96 \\
56-59 \\
84-86 \\
98-93 \\
119-115 \\
84-81 \\
80-81 \\
75 \\
86-88 \\
120 \\
90-86 \\
80 \\
110-114 \\
78-79 \\
108-106 \\
92 \\
110-106 \\
84-88 \\
92 \\
75-78 \\
78-80 \\
65-68 \\
77-81 \\
78-74 \\
84-84 \\
87-89 \\
90-91 \\
87-89 \\
91-92\end{array}$ & $\begin{array}{l}237 \\
305 \\
324 \\
218 \\
256 \\
322 \\
255 \\
309 \\
219 \\
342 \\
282 \\
312 \\
285 \\
309 \\
200 \\
242 \\
363 \\
204 \\
239 \\
239 \\
245 \\
282 \\
334 \\
252 \\
240 \\
196 \\
294 \\
279 \\
185 \\
198 \\
311 \\
264 \\
192 \\
204 \\
246 \\
242\end{array}$ & $\begin{array}{l}215 \\
255 \\
260 \\
194 \\
228 \\
268 \\
230 \\
260 \\
192 \\
296 \\
258 \\
288 \\
240 \\
264 \\
187 \\
192 \\
321 \\
180 \\
192 \\
224 \\
206 \\
257 \\
226 \\
238 \\
200 \\
164 \\
250 \\
251 \\
171 \\
170 \\
244 \\
228 \\
177 \\
181 \\
218 \\
222\end{array}$ & $\begin{array}{l}183 \\
227 \\
220 \\
168 \\
217 \\
228 \\
218 \\
233 \\
180 \\
272 \\
236 \\
270 \\
210 \\
231 \\
171 \\
178 \\
302 \\
169 \\
164 \\
212 \\
180 \\
242 \\
218 \\
225 \\
190 \\
146 \\
210 \\
208 \\
152 \\
155 \\
185 \\
217 \\
165 \\
162 \\
194 \\
203\end{array}$ & $\begin{array}{l}169 \\
212 \\
196 \\
152 \\
194 \\
180 \\
200 \\
212 \\
168 \\
240 \\
224 \\
250 \\
190 \\
209 \\
157 \\
156 \\
261 \\
160 \\
140 \\
204 \\
170 \\
226 \\
207 \\
212 \\
176 \\
142 \\
180 \\
197 \\
138 \\
146 \\
157 \\
204 \\
153 \\
147 \\
184 \\
189\end{array}$ & $\begin{array}{l}163 \\
196 \\
172 \\
144 \\
190 \\
166 \\
192 \\
182 \\
158 \\
218 \\
210 \\
228 \\
169 \\
192 \\
138 \\
143 \\
242 \\
147 \\
133 \\
199 \\
145 \\
205 \\
189 \\
201 \\
164 \\
112 \\
162 \\
182 \\
123 \\
139 \\
124 \\
198 \\
145 \\
140 \\
166 \\
175\end{array}$ & $\begin{array}{l}152 \\
181 \\
152 \\
134 \\
174 \\
140 \\
171 \\
170 \\
147 \\
200 \\
195 \\
218 \\
151 \\
176 \\
126 \\
132 \\
210 \\
135 \\
121 \\
192 \\
137 \\
200 \\
178 \\
191 \\
159 \\
110 \\
141 \\
169 \\
118 \\
129 \\
107 \\
189 \\
137 \\
126 \\
152 \\
168\end{array}$ & $\begin{array}{r}145 \\
170 \\
141 \\
127 \\
166 \\
108 \\
163 \\
157 \\
137 \\
183 \\
180 \\
206 \\
137 \\
162 \\
116 \\
116 \\
206 \\
128 \\
109 \\
180 \\
128 \\
185 \\
163 \\
183 \\
148 \\
90 \\
114 \\
159 \\
101 \\
123 \\
96 \\
180 \\
131 \\
119 \\
141 \\
154\end{array}$ & $\begin{array}{r}129 \\
112 \\
120 \\
157 \\
84 \\
132 \\
142 \\
120 \\
166 \\
170 \\
195 \\
124 \\
150 \\
99 \\
98 \\
195 \\
112 \\
95 \\
170 \\
107 \\
176 \\
154 \\
175 \\
141 \\
86 \\
102 \\
149 \\
92 \\
117 \\
87 \\
172 \\
119 \\
115 \\
129 \\
146\end{array}$ & $\begin{array}{l}0.75 \\
1.08 \\
1.51 \\
0.88 \\
0.78 \\
2.02 \\
0.91 \\
1.22 \\
0.79 \\
1.25 \\
0.90 \\
0.94 \\
1.33 \\
1.17 \\
1.23 \\
1.15 \\
1.06 \\
0.94 \\
1.26 \\
0.51 \\
1.17 \\
0.80 \\
0.82 \\
0.67 \\
0.68 \\
1.26 \\
1.82 \\
0.98 \\
1.15 \\
0.73 \\
2.36 \\
0.53 \\
0.75 \\
1.10 \\
1.12 \\
1.02\end{array}$ & $\begin{array}{l}1.84 \\
2.12 \\
2.89 \\
2.78 \\
1.61 \\
3.07 \\
1.60 \\
2.43 \\
1.26 \\
2.02 \\
1.44 \\
1.61 \\
2.43 \\
2.06 \\
2.49 \\
2.71 \\
1.80 \\
2.19 \\
3.05 \\
1.27 \\
2.31 \\
1.85 \\
1.73 \\
1.57 \\
1.49 \\
4.62 \\
3.08 \\
1.61 \\
2.39 \\
1.73 \\
5.22 \\
1.02 \\
1.76 \\
2.73 \\
2.28 \\
1.88\end{array}$ & $\begin{array}{l}222 \\
231 \\
231 \\
187 \\
228 \\
221 \\
207 \\
244 \\
184 \\
270 \\
227 \\
269 \\
220 \\
243 \\
172 \\
171 \\
267 \\
174 \\
179 \\
213 \\
186 \\
342 \\
287 \\
237 \\
234 \\
173 \\
221 \\
193 \\
154 \\
154 \\
218 \\
213 \\
169 \\
173 \\
196 \\
199\end{array}$ & $\begin{array}{r}99 \\
120 \\
127 \\
74 \\
121 \\
138 \\
116 \\
133 \\
118 \\
177 \\
157 \\
130 \\
128 \\
149 \\
86 \\
80 \\
152 \\
79 \\
81 \\
99 \\
100 \\
99 \\
126 \\
115 \\
128 \\
52 \\
132 \\
128 \\
82 \\
66 \\
106 \\
126 \\
62 \\
67 \\
101 \\
105\end{array}$ & $\begin{array}{l}1.67 \\
2.49 \\
3.49 \\
1.65 \\
1.78 \\
4.47 \\
1.88 \\
2.98 \\
1.48 \\
2.97 \\
2.36 \\
2.56 \\
2.99 \\
2.91 \\
2.11 \\
1.97 \\
2.83 \\
1.64 \\
2.26 \\
1.09 \\
2.17 \\
2.73 \\
2.34 \\
1.61 \\
1.69 \\
2.24 \\
4.02 \\
1.89 \\
1.58 \\
1.00 \\
5.76 \\
1.13 \\
1.41 \\
2.63 \\
2.27 \\
2.07\end{array}$ & $\begin{array}{l}1.82 \\
2.54 \\
3.67 \\
2.06 \\
1.95 \\
4.23 \\
1.89 \\
3.23 \\
1.52 \\
3.15 \\
2.60 \\
2.11 \\
3.17 \\
3.13 \\
2.14 \\
2.17 \\
2.74 \\
1.73 \\
2.47 \\
1.26 \\
2.31 \\
1.83 \\
2.18 \\
1.83 \\
2.02 \\
2.48 \\
4.07 \\
2.05 \\
1.75 \\
1.00 \\
6.20 \\
1.29 \\
1.22 \\
2.67 \\
2.36 \\
2.01\end{array}$ \\
\hline $\begin{array}{l}\text { Avera } \\
\text { S.D. }\end{array}$ & $\begin{array}{l}89 \\
13\end{array}$ & $\begin{array}{r}262 \\
46\end{array}$ & $\begin{array}{r}226 \\
40\end{array}$ & $\begin{array}{r}204 \\
34\end{array}$ & $\begin{array}{r}186 \\
32\end{array}$ & $\begin{array}{r}171 \\
31\end{array}$ & $\begin{array}{r}155 \\
30\end{array}$ & $\begin{array}{r}146 \\
30\end{array}$ & $\begin{array}{r}132 \\
31\end{array}$ & $\begin{array}{l}1.06 \\
0.33\end{array}$ & $\begin{array}{l}2.22 \\
0.85\end{array}$ & $\begin{array}{r}209 \\
40\end{array}$ & $\begin{array}{r}102 \\
9\end{array}$ & $\begin{array}{l}2.34 \\
0.91\end{array}$ & $\begin{array}{l}2.41 \\
0.96\end{array}$ \\
\hline
\end{tabular}

* Diagnoses: Cases 20, 21, 24, 26-28, 30, 32, 33: Carcinoma of cervix, Stage I or II ; Cases 22, 23, 29, 31: Carcinoma of breast; Case 25: Carcinoma of lung; Cases 39, 43, 49, 54, 55: Chronic myelogenous leukemia; Cases 34, 37, 53: Chronic lymphatic leukemia; Cases 35, 40-42, 44, 47: Hodgkins; Cases 46, 48, 50-52: Lymphosarcoma; Cases 36, 38, 45, 50: Reticulum cell sarcoma.

+ Where single value for fasting glucose is given, only one fasting blood sample was obtained.

$\mp$ Refer to text for definition of these items and methods of calculating their values.

they were found to provide good reproducibility in a given individual, and good discrimination between the control and neoplastic groups.

The intravenous glucose tolerance curve may be analyzed by plotting the log of the total blood glucose concentration against time to obtain a straight line (22). This relationship suggests that the rate of fall of blood glucose at any time is proportional to the total blood glucose value at that time.

Amatuzio and his co-workers (23) found that the plot of the log of the blood glucose value in excess of the initial fasting level against time was a straight line. These authors suggested, therefore, that the rate of fall of blood glucose at any time is proportional to the blood glucose concentration in excess of the fasting level at that time.
An index of glucose tolerance may be obtained by plotting the data according to either of the above indicated methods and then applying the equation:

$$
K=\frac{\log _{0} 2}{t_{1}}
$$

where in determining the fractional rate constant of disappearance of "total glucose" $\left(K_{b}\right), t_{2 / 3}$ is the time in minutes required for the total blood sugar value at any point to decline 50 per cent, or, in determining the fractional rate constant of disappearance of "increment glucose" $\left(\mathrm{K}_{\mathrm{R}}\right), \mathrm{t}_{1 / 2}$ is the time in minutes required for the blood sugar value in excess of the fasting level at any point to decline $\mathbf{5 0}$ per cent.

Analysis of the present data, in accord with previously published studies $(24,25)$, indicates that neither of the 
methods $(22,23)$ mentioned above describes the entire glucose tolerance curve. Thus, the values of blood glucose at eight minutes and at times when the concentrations of blood glucose were below $25 \mathrm{mg}$. per cent in excess of the fasting value generally deviated from the simple exponential relationship. In this study, the blood sugar values between 16 minutes and 56 minutes following the beginning of the glucose injection were employed for graphic analysis. In addition, $\mathrm{K}_{\mathrm{b}}$ and $\mathrm{K}_{\mathrm{a}}$ were calculated, by the method of least squares, for each glucose tolerance test. The $K$ values as determined 1) by this calculation and 2) by free-hand graphic analysis did not differ significantly, as shown by comparison of the means of the two paired samples.

The reliability of $K_{a}$ and $K_{b}$ in analysis of the present glucose tolerance data was further evaluated by two types of statistical analysis. First, employing the data obtained in repeat determinations in ten patients (Table III), analysis of variance revealed that both $K_{b}$ and $K_{2}$ showed

4 In actual practice, the constants were calculated in terms of the $\log$ to the base 10 and in terms of 8-minute periods. The constants (C) calculated in this manner were related to $K_{b}$ or $K_{a}$ by the equation:

$$
2.3 \mathrm{C}=8 \mathrm{~K}
$$

a very small variation between repeat determinations in the same individual relative to the variation between individuals (Table IV). Amatuzio, Stutzman, Vanderbilt, and Nesbitt (23) have shown by duplicate tests in normal individuals that $K_{a}$ is reproducible. Recently, Duncan (24) has demonstrated the reproducibility of both $K_{a}$ and $\mathrm{K}_{\mathrm{b}}$ in normal individuals. Secondly, employing the initial glucose tolerance test in each of the entire group of control and patient subjects, analysis of variance revealed that both $K_{b}$ and $K_{a}$ distinguished significantly between these groups (Table V). Furthermore, the discrimination between the neoplastic and normal group was equally good whether $K_{b}$ or $K_{a}$ was employed in analysis of the data (Table V).

It should be noted that the two methods employed in the analysis of the intravenous glucose tolerance curves are empirical and suggest different and mutually exclusive assumptions about the mechanisms controlling the rate of glucose disappearance. The present data indicate that while neither method is a completely accurate description of blood glucose disappearance, both fit the data sufficiently closely to provide good means of assessing glucose tolerance.

Net rate of disappearance of glucose. $\mathrm{K}_{\mathrm{b}}$ and $\mathrm{K}_{\mathrm{a}}$ provide a value for the fractional rate constant of glucose

TABLE III

Repeat intravenous glucose tolerance tests in patients with neoplastic disease

\begin{tabular}{|c|c|c|c|c|c|c|c|c|c|c|c|c|}
\hline \multirow{2}{*}{$\begin{array}{l}\text { Subject } \\
\text { No. }\end{array}$} & \multirow[b]{2}{*}{ Date } & \multirow{2}{*}{$\begin{array}{l}\text { Fasting } \\
\text { glucose* }\end{array}$} & \multicolumn{8}{|c|}{$\begin{array}{c}\text { Glucose concentration (mgm. \%) } \\
\text { (Time in minutes) }\end{array}$} & \multicolumn{2}{|c|}{$\begin{array}{c}\text { Disappearance } \\
\text { rate constant } \\
(\% / \operatorname{min.})\end{array}$} \\
\hline & & & 8 & 16 & 24 & 32 & 40 & 48 & 56 & 64 & Total & Increment \\
\hline 41 & $\begin{array}{l}6 / 22 \\
7 / 8\end{array}$ & $\begin{array}{l}108-106 \\
114-120\end{array}$ & $\begin{array}{l}282 \\
283\end{array}$ & $\begin{array}{l}257 \\
258\end{array}$ & $\begin{array}{l}242 \\
241\end{array}$ & $\begin{array}{l}226 \\
224\end{array}$ & $\begin{array}{l}205 \\
210\end{array}$ & $\begin{array}{l}200 \\
198\end{array}$ & $\begin{array}{l}185 \\
188\end{array}$ & $\begin{array}{l}176 \\
180\end{array}$ & $\begin{array}{l}0.80 \\
0.84\end{array}$ & $\begin{array}{l}1.85 \\
1.76\end{array}$ \\
\hline 42 & $\begin{array}{l}4 / 15 \\
4 / 21\end{array}$ & $\begin{array}{r}92 \\
96-100\end{array}$ & $\begin{array}{l}334 \\
276\end{array}$ & $\begin{array}{l}226 \\
231\end{array}$ & $\begin{array}{l}218 \\
196\end{array}$ & $\begin{array}{l}207 \\
186\end{array}$ & $\begin{array}{l}189 \\
187\end{array}$ & $\begin{array}{l}178 \\
174\end{array}$ & $\begin{array}{l}163 \\
161\end{array}$ & $\begin{array}{l}154 \\
150\end{array}$ & $\begin{array}{l}0.82 \\
0.82\end{array}$ & $\begin{array}{l}1.73 \\
1.87\end{array}$ \\
\hline 43 & $\begin{array}{l}5 / 6 \\
5 / 12 \\
5 / 19\end{array}$ & $\begin{array}{r}110-106 \\
115-109 \\
118\end{array}$ & $\begin{array}{l}252 \\
320 \\
278\end{array}$ & $\begin{array}{l}238 \\
271 \\
258\end{array}$ & $\begin{array}{l}225 \\
257 \\
241\end{array}$ & $\begin{array}{l}212 \\
222 \\
226\end{array}$ & $\begin{array}{l}201 \\
217 \\
212\end{array}$ & $\begin{array}{l}191 \\
200 \\
201\end{array}$ & $\begin{array}{l}183 \\
190 \\
197\end{array}$ & $\begin{array}{l}175 \\
176 \\
185\end{array}$ & $\begin{array}{l}0.67 \\
0.78 \\
0.76\end{array}$ & $\begin{array}{l}1.57 \\
1.80 \\
1.60\end{array}$ \\
\hline 44 & $\begin{array}{l}7 / 6 \\
9 / 8\end{array}$ & $\begin{array}{l}86-86 \\
78-80\end{array}$ & $\begin{array}{l}240 \\
197\end{array}$ & $\begin{array}{l}200 \\
185\end{array}$ & $\begin{array}{l}190 \\
168\end{array}$ & $\begin{array}{l}176 \\
160\end{array}$ & $\begin{array}{l}164 \\
149\end{array}$ & $\begin{array}{l}159 \\
144\end{array}$ & $\begin{array}{l}148 \\
136\end{array}$ & $\begin{array}{l}141 \\
128\end{array}$ & $\begin{array}{l}0.68 \\
0.63\end{array}$ & $\begin{array}{l}1.49 \\
1.54\end{array}$ \\
\hline 47 & $\begin{array}{l}9 / 1 \\
1 / 12\end{array}$ & $\begin{array}{l}78-80 \\
86-84\end{array}$ & $\begin{array}{l}279 \\
300\end{array}$ & $\begin{array}{l}251 \\
288\end{array}$ & $\begin{array}{l}208 \\
256\end{array}$ & $\begin{array}{l}197 \\
233\end{array}$ & $\begin{array}{l}182 \\
215\end{array}$ & $\begin{array}{l}169 \\
199\end{array}$ & $\begin{array}{l}159 \\
184\end{array}$ & $\begin{array}{l}149 \\
170\end{array}$ & $\begin{array}{l}0.98 \\
1.02\end{array}$ & $\begin{array}{l}1.61 \\
1.61\end{array}$ \\
\hline 48 & $\begin{array}{r}9 / 12 \\
11 / 18\end{array}$ & $\begin{array}{l}65-68 \\
79-78\end{array}$ & $\begin{array}{l}185^{\circ} \\
232\end{array}$ & $\begin{array}{l}171 \\
200\end{array}$ & $\begin{array}{l}152 \\
179\end{array}$ & $\begin{array}{l}138 \\
158\end{array}$ & $\begin{array}{l}123 \\
142\end{array}$ & $\begin{array}{l}118 \\
130\end{array}$ & $\begin{array}{l}101 \\
120\end{array}$ & $\begin{array}{r}92 \\
111\end{array}$ & $\begin{array}{l}1.15 \\
1.25\end{array}$ & $\begin{array}{l}2.39 \\
2.51\end{array}$ \\
\hline 49 & $\begin{array}{l}9 / 23 \\
1 / 12\end{array}$ & $\begin{array}{l}77-81 \\
82-90\end{array}$ & $\begin{array}{l}198 \\
264\end{array}$ & $\begin{array}{l}170 \\
218\end{array}$ & $\begin{array}{l}155 \\
201\end{array}$ & $\begin{array}{l}146 \\
191\end{array}$ & $\begin{array}{l}139 \\
180\end{array}$ & $\begin{array}{l}129 \\
168\end{array}$ & $\begin{array}{l}123 \\
158\end{array}$ & $\begin{array}{l}117 \\
147\end{array}$ & $\begin{array}{l}0.73 \\
0.80\end{array}$ & $\begin{array}{l}1.73 \\
1.57\end{array}$ \\
\hline 52 & $\begin{array}{c}11 / 21 \\
1 / 3\end{array}$ & $\begin{array}{l}87-89 \\
86-85\end{array}$ & $\begin{array}{l}192 \\
196\end{array}$ & $\begin{array}{l}177 \\
189\end{array}$ & $\begin{array}{l}165 \\
164\end{array}$ & $\begin{array}{l}153 \\
154\end{array}$ & $\begin{array}{l}145 \\
142\end{array}$ & $\begin{array}{l}137 \\
138\end{array}$ & $\begin{array}{l}131 \\
125\end{array}$ & $\begin{array}{l}121 \\
118\end{array}$ & $\begin{array}{l}0.75 \\
0.79\end{array}$ & $\begin{array}{l}1.76 \\
1.86\end{array}$ \\
\hline 54 & $\begin{array}{l}2 / 23 \\
3 / 1 \\
3 / 8\end{array}$ & $\begin{array}{l}81-89 \\
79-82 \\
80-81\end{array}$ & $\begin{array}{l}246 \\
228 \\
240\end{array}$ & $\begin{array}{l}218 \\
192 \\
204\end{array}$ & $\begin{array}{l}194 \\
177 \\
192\end{array}$ & $\begin{array}{l}184 \\
162 \\
168\end{array}$ & $\begin{array}{l}166 \\
151 \\
156\end{array}$ & $\begin{array}{l}152 \\
136 \\
143\end{array}$ & $\begin{array}{l}141 \\
121 \\
132\end{array}$ & $\begin{array}{l}129 \\
112 \\
118\end{array}$ & $\begin{array}{l}1.12 \\
1.12 \\
1.19\end{array}$ & $\begin{array}{l}2.28 \\
2.15 \\
2.28\end{array}$ \\
\hline 55 & $\begin{array}{l}5 / 14 \\
5 / 24\end{array}$ & $\begin{array}{l}91-92 \\
90-92\end{array}$ & $\begin{array}{l}242 \\
264\end{array}$ & $\begin{array}{l}222 \\
240\end{array}$ & $\begin{array}{l}203 \\
222\end{array}$ & $\begin{array}{l}189 \\
206\end{array}$ & $\begin{array}{l}175 \\
184\end{array}$ & $\begin{array}{l}168 \\
175\end{array}$ & $\begin{array}{l}154 \\
164\end{array}$ & $\begin{array}{l}146 \\
150\end{array}$ & $\begin{array}{l}1.02 \\
1.02\end{array}$ & $\begin{array}{l}1.88 \\
2.01\end{array}$ \\
\hline
\end{tabular}

* Where a single value for fasting glucose is given, only one fasting blood sample was obtained. 
TABLE IV

Analysis of variance of indices of repeat glucose tolerance tests in ten patients with neoplastic disease

\begin{tabular}{|c|c|c|c|}
\hline & $\begin{array}{l}\text { Degrees } \\
\text { of } \\
\text { freedom }\end{array}$ & $\frac{\text { Total index }}{\substack{\text { Sum of } \\
\text { squares }}}$ & $\frac{\text { Increment inder }}{\substack{\text { Sum of } \\
\text { squares }}}$ \\
\hline $\begin{array}{l}\text { Between } \\
\text { individuals }\end{array}$ & 9 & .09951 & .57087 \\
\hline $\begin{array}{l}\text { Within } \\
\text { individuals }\end{array}$ & 10 & .00263 & .02477 \\
\hline $\begin{array}{l}\text { Total } \\
F^{*}\end{array}$ & 19 & 41.92 & 25.61 \\
\hline
\end{tabular}

For the number of degrees of freedom present in this table, an $F$ value greater than 4.95 would give a probability less than 0.01 .

disappearance, i.e., the per cent of glucose disappearing from the blood per minute. In an effort to evaluate the net amount of glucose disappearing from the blood, an estimate was made of the mean net rate of disappearance of glucose, i.e., the milligrams of glucose disappearing per unit volume of blood per minute. The term net is used to indicate that this value represents the resultant of those reactions removing glucose from the blood and those reactions delivering glucose to the blood. In order to obtain the mean net rate of disappearance of "total glucose" from the blood per minute (G.D.b), the average "total glucose" concentration was multiplied by the rate constant $K_{b}$. The mean net rate of disappearance of "increment glucose" from the blood (G.D.a) was derived by multiplying $K_{2}$ by the mean glucose concentration in excess of the fasting level.5 All values for net rate of disappearance of glucose, in subjects receiving other than $25 \mathrm{gm}$. of glucose, were corrected to this dose. The value obtained for mean net rate of disappearance of glucose is

- The value for the average "total glucose" concentration was obtained by the equation:

$$
\bar{G}_{b}=\frac{G_{0}\left(1-e^{-K_{b} t}\right)}{t K_{b}},
$$

where $\bar{G}_{b}$ is the average "total glucose" concentration in mgm. per $100 \mathrm{cc}$; $\mathrm{G}_{0}$ is the total blood glucose concentration in mgm. per $100 \mathrm{cc}$. at zero time; $t$ is the time interval in minutes during which the fractional rate of "total glucose" disappearance is constant.

The value for the average "increment glucose" concentration was obtained by the equation:

$$
\bar{G}_{\mathrm{a}}=\frac{\left(\mathrm{G}_{0}-\mathrm{G}_{\mathrm{f}}\right)\left(1-\mathrm{e}^{-\mathrm{K}_{\mathrm{a}} \mathrm{t}}\right)}{\mathrm{t} \mathrm{K_{ \textrm {a } }}} \text {, }
$$

where $\bar{G}_{\mathrm{a}}$ is the average "increment glucose" concentration in mgm. per $100 \mathrm{cc}$; $\mathrm{G}_{\mathrm{t}}$ is the fasting blood glucose concentration in mgm. per $100 \mathrm{cc}$; $t$ is the time interval in minutes during which the fractional rate of "increment glucose" disappearance is constant. defined by the method employed in its calculation. It is used in this study only for the purpose of comparing the control and neoplastic groups with respect to this parameter. The value for G.D.b would be expected to be equal to the value for G.D.a if both a plot of the log of the "total glucose" concentration against time and a plot of the $\log$ of the "increment glucose" concentration against time represent good approximations of a straight line.

Estimation of volume of distribution of glucose. An estimate of the volume of distribution of glucose (EVG) was obtained in those subjects in whom the glucose was given using a constant infusion pump to permit an accurate determination of the volume of glucose solution injected. The EVG was calculated by dividing the amount of glucose injected (mgm.) by the glucose concentration in excess of the fasting value (mgm. per $100 \mathrm{cc}$.) at the end of injection. This glucose concentration was determined by extrapolating to the end of the injection period the linear plot of the log of the glucose concentration in excess of the fasting level between 16 and 56 minutes following the injections. The values for blood sugar concentration prior to 16 minutes generally fell above this line and were not employed in this graphic analysis to reduce the error due to mixing. It is recognized that this calculation is not free from objection, particularly when applied to metabolizable substances. Nevertheless, it is assumed that these errors will be similar in both control and neoplastic subjects.

\section{RESULTS}

The data obtained from intravenous glucose tolerance tests in 19 control subjects and $36 \mathrm{pa}$ tients with neoplastic diseases are presented in Tables I and II. The diagnosis of each subject is indicated in these tables.

\section{Fractional rate constant of glucose disappearance}

The fractional rate of "total glucose" disappearance $\left(\mathrm{K}_{\mathrm{b}}\right)$ for the control group was $1.97 \pm$

TABLE $V$

Analysis of variance comparing the glucose tolerance tests in

\begin{tabular}{|c|c|c|c|}
\hline & & $\begin{array}{l}\text { Total blood } \\
\text { sugar index }\end{array}$ & $\begin{array}{l}\text { Increment blood } \\
\text { sugar index }\end{array}$ \\
\hline & of & $\begin{array}{l}\text { Sum of } \\
\text { squares }\end{array}$ & $\begin{array}{l}\text { Sum of } \\
\text { squares }\end{array}$ \\
\hline $\begin{array}{l}\text { Between groups } \\
\text { Within groups }\end{array}$ & $\begin{array}{r}1 \\
54\end{array}$ & $\begin{array}{r}.64261 \\
1.66644\end{array}$ & $\begin{array}{l}10.38503 \\
27.77842\end{array}$ \\
\hline $\begin{array}{l}\text { Total } \\
F^{*}\end{array}$ & 55 & $\begin{array}{l}2.30905 \\
20.82\end{array}$ & $\begin{array}{l}38.16345 \\
20.18\end{array}$ \\
\hline
\end{tabular}
control subjects and patients with neoplastic disease

For the number of degrees of freedom present in this table, an $F$ value greater than 7.12 would give a probability less than 0.01 . 


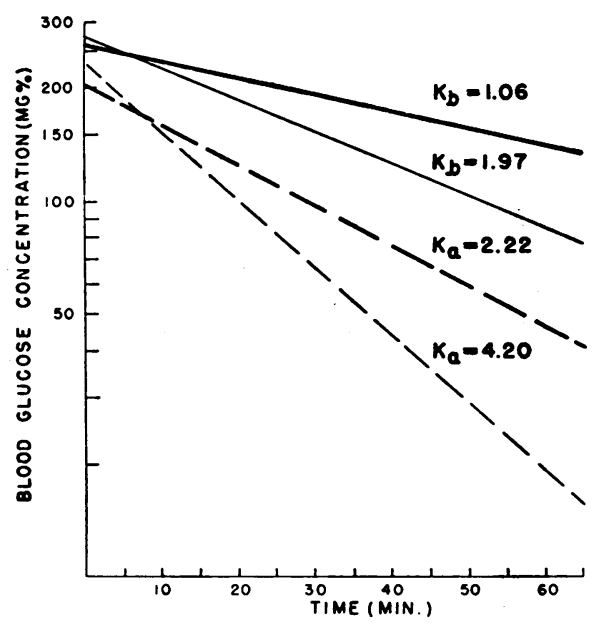

Fig. 1. The Average Curves of Total Blood Glucose Concentration Against Time are Plotted for the Control (Light Solid Line) and Patient (Heavy Solid Line) Groups and the Average Curves of the Blood Sugar Concentration in Excess of the Fasting Level Against Time are Plotted for the Control (Light Broken Line) and Patient (Heavy Broken LiNe) Groups

The fractional rate of disappearance of "total glucose" $\left(K_{b}\right)$ and the fractional rate of disappearance of "increment glucose" $\left(\mathrm{K}_{\mathbf{a}}\right)$ are indicated in per cent per minute.

0.62 per cent per minute. ${ }^{6}$ The $\mathrm{K}_{\mathrm{b}}$ for the neoplastic group was $1.06 \pm 0.33$ per cent per minute. The fractional rate of "increment glucose" disappearance $\left(\mathrm{K}_{\mathrm{a}}\right)$ in the control group averaged $4.20 \pm 1.52$ per cent per minute. The neoplastic group had a $\mathrm{K}_{\mathrm{a}}$ of $2.22 \pm 0.85$ per cent per minute. The difference between the means for both $\mathrm{K}_{\mathrm{a}}$ and $\mathrm{K}_{\mathrm{b}}$ were statistically significant ${ }^{7}$ (Figure 1). Examination of Tables I and II will reveal that $\mathrm{K}_{\mathbf{b}}$ in five subjects with neoplastic disease and $\mathrm{K}_{\mathrm{a}}$ in six of these patients fell within the range. of values for the control series.

The data for the control subjects are in general agreement with previous results obtained using the type of intravenous glucose tolerance test employed in this study. In 60 normal subjects reported by Lozner, Winkler, Taylor, and Peters (26), the $K_{b}$ was $1.96 \pm 0.30$ per cent per minute and the $K_{a}$ was $3.57 \pm 0.37$ per cent per minute. Amatuzio, Stutzman, Vanderbilt, and Nesbitt (23) reported data on 70 control individuals with $a K_{b}$

- Average values are given with one standard deviation.

7 A significant difference between the means was taken to be a difference of at least 3.2 times the standard deviation of the difference between means $(p<.01)$. of $1.34 \pm 0.27$ per cent per minute and $a \mathrm{~K}_{\mathrm{a}}$ of $3.71 \pm 0.40$ per cent per minute. An average $K_{b}$ of $1.52 \pm 0.23$ per cent per minute has been observed in 20 normal subjects (22). In 20 normal persons, Duncan (24) found a $K_{b}$ of $1.37 \pm 0.22$ per cent per minute and $a K_{a}$ of $3.68 \pm 0.40$ per cent per minute.

\section{Blood sugar values}

The fasting blood sugar for the control series was $83 \pm 8 \mathrm{mgm}$. per cent and for the neoplastic group $89 \pm 13 \mathrm{mgm}$. per cent (Tables I and II). The difference between these means was not statistically significant. Four patients with neoplastic disease did have fasting blood sugars in excess of $100 \mathrm{mgm}$. per cent, which was the upper value for the range of fasting blood sugar levels in the control group.

The average blood sugar values for the control and neoplastic groups at 8 and 16 minutes following glucose administration were not significantly different. The mean blood sugar concentrations at subsequent sampling times, i.e., $24,32,40,56$ and 64 minutes, following glucose administration were significantly higher in the patients with neoplastic disease than in the control individuals (Tables I and II).

Urinary glucose excretion during the $75 \mathrm{~min}$ utes following the intravenous administration of glucose was determined in 14 control individuals and 22 patients. Urinary glucose excretion amounted to $0.8 \pm 0.3 \mathrm{gm}$. during the 75 -minute period in control individuals and $0.6 \pm 0.3 \mathrm{gm}$. during the 75-minute period in the neoplastic group. There was no significant difference between these means.

\section{Net rate of disappearance of glucose}

The mean "total glucose" concentration $\left(\bar{G}_{\mathbf{b}}\right)$ was $180 \pm 29 \mathrm{mgm}$. per cent in the control individuals and $209 \pm 40 \mathrm{mgm}$. per cent in the neoplastic group. In the control group, the net rate of disappearance of "total glucose" from the blood (G.D.b) was $3.74 \pm 1.04$ mgm. per 100 cc. per minute compared with a value of $2.34 \pm 0.91 \mathrm{mgm}$. per 100 cc. per minute for the individuals with neoplastic disease (Tables I and II). The difference between the mean G.D.b and the difference 
TABLE VI

Estimated glucose volume of distribution in control and neoplastic subjects

\begin{tabular}{|c|c|c|c|c|c|c|c|}
\hline \multicolumn{4}{|c|}{ Control subjects } & \multicolumn{4}{|c|}{ Neoplastic subjects } \\
\hline $\begin{array}{l}\text { Subject } \\
\text { No. }\end{array}$ & $\begin{array}{c}\text { Glucose } \\
\text { administered } \\
(\mathrm{gm} .)\end{array}$ & $\underset{\text { (liters) }}{\mathbf{V}}$ & $\begin{array}{c}\mathbf{V} \\
(\% \text { of } B W)\end{array}$ & $\begin{array}{l}\text { Subject } \\
\text { No.* }\end{array}$ & $\begin{array}{c}\text { Glucose } \\
\text { administered } \\
(\text { (gm.) }\end{array}$ & $\underset{\text { (liters) }}{\mathbf{V}}$ & $(\%$ of $B W)$ \\
\hline $\begin{array}{l}10 \\
12 \\
13 \\
14 \\
15 \\
16 \\
17 \\
18 \\
19\end{array}$ & $\begin{array}{l}25.0 \\
19.9 \\
19.3 \\
21.0 \\
23.4 \\
25.0 \\
25.3 \\
23.7 \\
22.9\end{array}$ & $\begin{array}{l}11.9 \\
10.5 \\
13.3 \\
15.6 \\
10.6 \\
12.1 \\
15.8 \\
14.8 \\
11.8\end{array}$ & $\begin{array}{l}18.3 \\
16.1 \\
15.8 \\
25.5 \\
17.8 \\
17.5 \\
26.4 \\
21.2 \\
16.6\end{array}$ & $\begin{array}{l}28 \\
29 \\
30 \\
31 \\
32 \\
33 \\
43 \mathrm{~B} \\
\mathrm{C} \\
44 \mathrm{~B} \\
45\end{array}$ & $\begin{array}{l}24.4 \\
28.5 \\
21.7 \\
24.8 \\
24.4 \\
24.4 \\
24.6 \\
24.6 \\
23.7 \\
24.2\end{array}$ & $\begin{array}{r}11.8 \\
9.2 \\
11.0 \\
11.3 \\
11.1 \\
10.2 \\
16.4 \\
16.2 \\
17.2 \\
17.0\end{array}$ & $\begin{array}{l}20.7 \\
19.7 \\
17.8 \\
17.4 \\
23.5 \\
17.9 \\
26.6 \\
26.3 \\
22.8 \\
19.1\end{array}$ \\
\hline \multirow[t]{2}{*}{$\begin{array}{c}\text { Average } \\
\text { S.D. }\end{array}$} & 22.8 & $\begin{array}{r}12.9 \\
1.8\end{array}$ & $\begin{array}{r}19.5 \\
3.8\end{array}$ & $\begin{array}{r}47 \mathrm{~B} \\
48 \mathrm{~A} \\
\mathrm{~B} \\
49 \mathrm{~A} \\
\mathrm{~B} \\
50 \\
51 \\
52 \mathrm{~A} \\
\mathrm{~B} \\
53 \\
54 \mathrm{~A} \\
\mathrm{~B} \\
\mathrm{C} \\
55 \mathrm{~A} \\
\mathrm{~B}\end{array}$ & $\begin{array}{l}25.0 \\
28.2 \\
24.0 \\
28.3 \\
25.1 \\
22.4 \\
25.0 \\
22.4 \\
23.4 \\
17.1 \\
24.2 \\
24.2 \\
25.3 \\
24.6 \\
24.0\end{array}$ & $\begin{array}{r}10.8 \\
16.8 \\
17.5 \\
14.5 \\
15.5 \\
7.6 \\
15.6 \\
15.7 \\
15.5 \\
12.8 \\
16.1 \\
15.4 \\
15.2 \\
13.3 \\
14.5\end{array}$ & $\begin{array}{l}18.5 \\
21.4 \\
22.7 \\
25.3 \\
26.6 \\
12.0 \\
26.4 \\
23.8 \\
25.8 \\
17.3 \\
25.5 \\
24.4 \\
24.1 \\
21.8 \\
21.7\end{array}$ \\
\hline & & & & $\begin{array}{c}\text { Average } \\
\text { S.D. }\end{array}$ & 24.3 & $\begin{array}{r}13.2 \\
3.0\end{array}$ & $\begin{array}{r}21.0 \\
3.8\end{array}$ \\
\hline
\end{tabular}

* Letters refer to repeat determinations at time of repeat glucose tolerance tests (Table III).

between the average $G_{b}$ for the control and patient groups were statistically significant.

The mean "increment glucose" concentration $\left(\bar{G}_{a}\right)$ for the control subjects had a value of $89 \pm$ $24 \mathrm{mgm}$. per cent compared with $102 \pm 9 \mathrm{mgm}$. per cent for the neoplastic patients. Net rate of disappearance of "increment glucose" (G.D.a) was $3.68 \pm 0.93 \mathrm{mgm}$. per $100 \mathrm{cc}$. per minute for the control subjects and $2.41 \pm 0.96 \mathrm{mgm}$. per $100 \mathrm{cc}$. per minute for the patients with neoplastic disease. The difference between the mean G.D.a was significant, though there was no significant difference between the average values for $\bar{G}_{a}$ for the control and patient groups. There is close agreement between the values for G.D.b and for G.D.a in both the control and neoplastic groups as predicted from the mathematical considerations indicated in the method section.

Examination of Tables I and II will reveal that G.D.b in 19 patients with malignant disease and G.D.a in 24 of these subjects fell within the range of values for the control group.

\section{Estimated volume of distribution of glucose}

Estimation of the volume of distribution of glucose (EVG) (Table VI) in control subjects yielded a value of $12.9 \pm 1.8$ liters or $19.5 \pm 3.8$ per cent of body weight, and in the neoplastic group a value of $13.2 \pm 3.0$ liters or $21.0 \pm 3.8$ per cent of body weight. These averages revealed that the EVG did not differ significantly between the two groups.

The values for EVG in the present study are in accord with previous findings. Jokipii and Turpeinen (27), using a 60-minute constant glucose infusion technique, reported a volume of distribution of glucose that averaged 17.0 per cent of body weight. One method (28), involving a single injection of carbon 14 labelled glucose, yielded an average volume of distribution of glucose of 24 per cent of body weight. Employing the same method as used in the present study, Dominguez (29) reported an average value of 19.0 per cent of body weight and Conard (30) found a mean 
of 24.3 per cent of body weight for the volume of distribution of glucose.

\section{Serum phosphate and serum potassium concentra- tion}

The fasting serum inorganic phosphate level in the control group was $3.19 \pm 0.36$ mgm. per cent compared with a value of $3.61 \pm 0.48 \mathrm{mgm}$. per cent for the patients with neoplastic disease. The difference between these means was statistically significant. The fasting serum potassium concentration had a value of $4.34 \pm 0.32 \mathrm{mEq}$. per liter in the control subjects and $4.45 \pm 0.34 \mathrm{mEq}$. per liter in the neoplastic individuals. These means did not differ significantly (Table VIII).

Most investigators consider the maximum fall in serum inorganic phosphate level and the maximum fall in serum potassium concentration as the important determinations in terms of reflecting glucose utilization, and the present data were analyzed from this standpoint. The maximum fall in serum inorganic phosphate in the control group was $0.67 \pm 0.19 \mathrm{mgm}$. per cent or $22.0 \pm 6.2$ per cent of the fasting level. In the neoplastic subjects, the maximum decrease in serum inorganic phosphate was $0.61 \pm 0.24 \mathrm{mgm}$. per cent or $16.7 \pm 5.7$ per cent of the fasting concentration. The difference between the mean values for the maximum fall of serum phosphate expressed in absolute terms was not significant. However, when the fall in serum phosphate concentration was expressed as a per cent of the fasting level, the difference between the means was of borderline significance. After a rapid injection of 25 gm. of glucose, Wertheim, Eurman, and Kalinsky (31) found a maximum fall in normals of $0.58 \pm$

TABLE VII

Serum inorganic phosphorus (mgm. \%) and potassium ( $m E g . / L$.$) concentrations during$ intravenous glucose tolerance tests

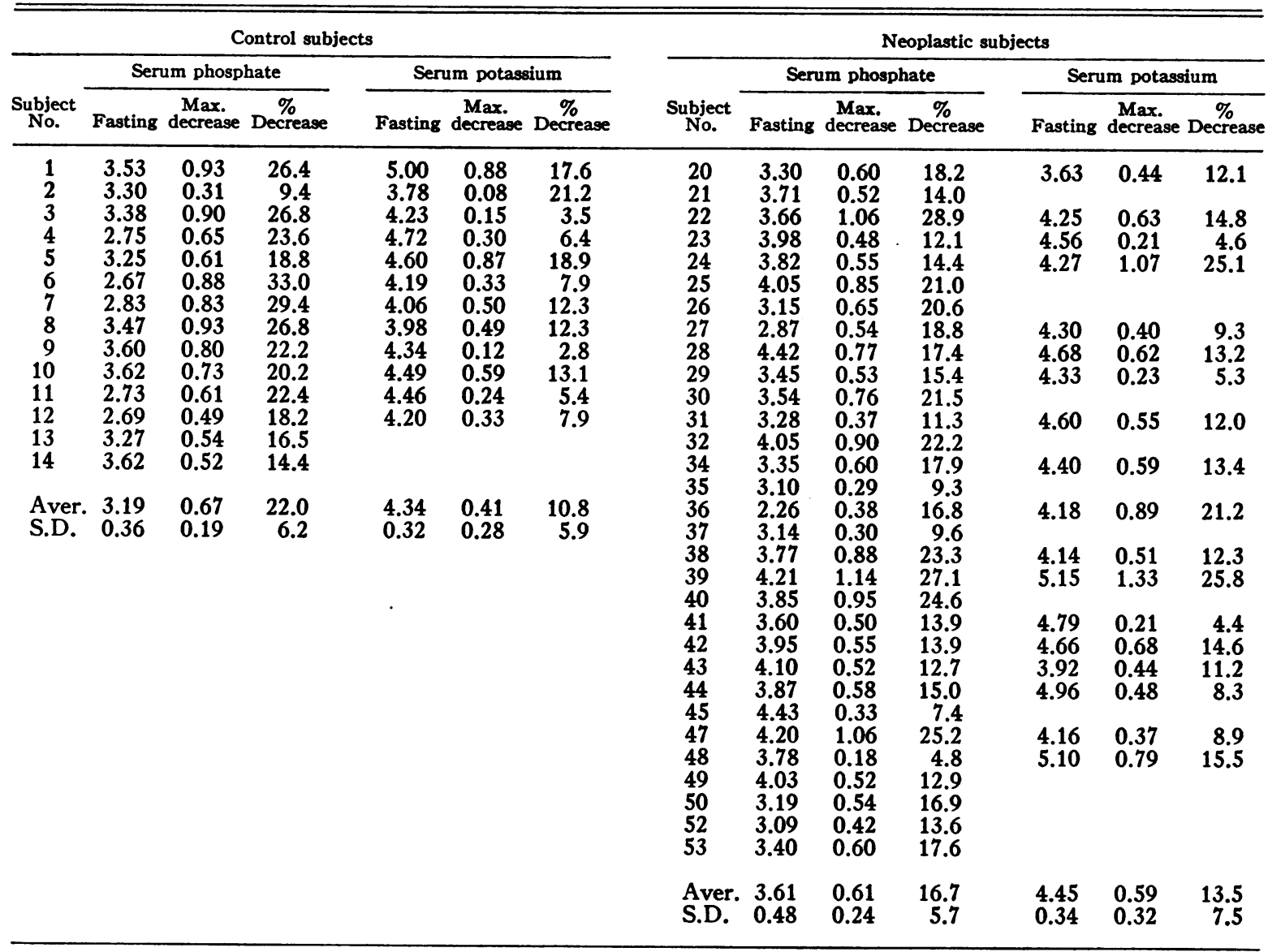


$0.24 \mathrm{mgm}$. per cent or $16.8 \pm 5.9$ per cent of the fasting value, and Lazarus, Volk, Jacobi, and Gilady (32) reported a mean maximum fall in normals of 14.2 per cent (10 to 22.5 per cent). These changes are more comparable to the findings in the patient group than in the normal individuals of the present study. It should be noted that in previous reports as well as in the present data, the range of values for maximum fall in serum inorganic phosphate is large.

The serum potassium concentration had a maximum fall of $0.41 \pm 0.28 \mathrm{mEq}$. per $\mathrm{L}$. or $10.8 \pm 5.9$ per cent of the fasting level in the control individuals. In the patient group, the maximum decrease in serum potassium was $0.59 \pm 0.32 \mathrm{mEq}$. per $\mathrm{L}$. or $13.5 \pm 7.5$ per cent of the fasting concentration. There was no statistically significant difference between the mean values for maximum fall, expressed in absolute or relative terms, in serum potassium concentration.

\section{DISCUSSION}

A decrease in glucose tolerance, as indicated by a slower fractional rate of disappearance of blood glucose, was found to be associated with the presence of malignant disease. The fasting blood sugar was within the normal range in these subjects. The group of patients studied included individuals with lymphoma, chronic leukemia, and clinically localized carcinoma of the cervix, and carcinoma of the breast. These individuals were carefully selected to exclude various other factors known to impair carbohydrate metabolism.

The slower fractional rate of disappearance of glucose in the patients with malignant disease was associated with a higher mean blood sugar concentration following the intravenous administration of glucose. The question arises, in view of these findings, as to whether the net amount of glucose disappearing from the blood in the neoplastic group differed from the control subjects. The mean value for the net rate of disappearance of glucose was significantly lower in the patients compared with the control group. However, in the patient group, a normal net rate of disappearance of glucose was more frequently observed than a normal fractional rate of disappearance of glucose. There was no difference in the estimated volume of distribution of glucose between the pa- tients and the control individuals. These calculated values derived from the disappearance curve of glucose indicate that in certain neoplastic subjects, despite a decreased fractional rate of disappearance of glucose, the persistence of blood glucose concentrations at significantly higher levels than in normal subjects may be associated with an approximately normal net rate of disappearance of glucose. A possible explanation of these findings is that net hepatic glucose output during the hyperglycemic phase is greater in the patients than in the control individuals and contributes to maintaining the higher blood glucose concentration. This explanation does not exclude a concomitant decrease in tissue glucose utilization in these patients.

The present data do not permit conclusions as to the mechanism of the decrease in glucose tolerance. A slower fractional rate of disappearance of glucose, whether or not associated with a decreased net rate of disappearance of glucose, might result from an alteration in hepatic glucose metabolism, a decrease in peripheral utilization, or a disturbance in both of these metabolic processes.

Peripheral glucose utilization has been found to be associated with a fall in serum inorganic phosphate following glucose administration (33, 34). A decrease in serum potassium concentration has also been reported to parallel glucose utilization (35). No statistically significant difference was observed between the control and patient groups with reference to the maximum fall in the absolute concentration of serum inorganic phosphate or serum potassium. The mean fasting serum inorganic phosphate concentration in the patients with malignant disease was higher than in the control subjects. The maximum fall in serum inorganic phosphate expressed as per cent of the fasting level was smaller in the patient group than in the control individuals. It should be noted that in the patients with malignant disease, the maximum decrease in serum inorganic phosphate concentration and in serum potassium concentration was found to be variable, and in any given individual the magnitude of fall of these two ions did not parallel each other. The meaning of these findings in terms of glucose metabolism is not apparent.

The fact that the decrease in glucose tolerance 
was associated with localized carcinoma, small in size relative to total body mass, would make it unlikely that, in these patients at least, the decreased rate of disappearance of glucose was attributable to the carbohydrate metabolism of the tumor. Indeed, Cori and Cori (36) demonstrated that tumor in vivo had an increased rate of glycolysis. It would appear that the defect in glucose metabolism reflects alterations in host tissue metabolism associated with the presence of the neoplastic process. In experimental animals, there are several reports of defects in enzyme activity (37), including enzymes involved in carbohydrate metabolism (38), of tissues of the tumorbearing host.

There are many studies on the incidence of cancer in diabetes mellitus (39). In general, these reports found that cancer occurs more frequently than expected in diabetics. The pertinence of this finding, if real, to the present data cannot be evaluated on the basis of available knowledge. The possibility does exist that the decrease in glucose tolerance in patients with malignant disease may reflect latent diabetes mellitus.

It should be emphasized that the defect in carbohydrate metabolism, as measured by the intravenous glucose tolerance test, is not at all specific. A decrease in glucose tolerance has been observed in a wide variety of conditions in addition to diabetes mellitus, such as endocrine disorders, hepatic disease, malnutrition, infectious diseases, neuropsychiatric disorders, renal disease and obesity. None of these conditions existed in the present group of patients with neoplastic disease. Thus, this defect in glucose metabolism can be considered of no diagnostic value; however, its definition may shed some light on the metabolic alterations associated with neoplasia, as well as other conditions in which a decreased glucose tolerance may be present.

\section{SUM MARY}

1. Intravenous glucose tolerance tests were performed in 36 carefully selected patients with chronic leukemia, lymphoma, and clinically early epithelial neoplasms, and in 19 subjects without cancer.

2. In analyzing the glucose tolerance curves, plotting either the log of the total blood sugar con- centration against time, or the log of the blood sugar concentration in excess of the fasting value against time, provided an equally good index of glucose tolerance.

3. The patients with malignant disease compared with the control subjects had a significantly decreased fractional rate of disappearance of glucose and a significantly lower net rate of disappearance of glucose.

4. The fasting blood sugar concentration of the control and neoplastic groups did not differ significantly.

5. No significant difference in the estimated volume distribution of glucose was found between the two groups.

6. In the patients with malignant disease, the fasting serum inorganic phosphate concentration was significantly greater and the maximum per cent fall in inorganic phosphate was significantly less than in the control individuals. No significant difference was observed in the fall in serum potassium concentration between the two groups.

\section{ACKNOWLEDGMENT}

The authors are indebted to Prof. John Fertig for his assistance in the statistical analysis of the present data. We are grateful to Miss Mae D'Orlando, R.N., Chief Nurse on the Metabolic Unit, for her assistance in the patient studies, and to Mrs. Ellen Zablow for her technical assistance.

\section{REFERENCES}

1. Marks, P. A., and Bishop, J., Glucose metabolism in human subjects with neoplastic diseases. J. Clin. Invest., 1956, 35, 722.

2. Freund, E., Zur Diagnose des Carcinoms. Vorläufige Mittheilung. Wien. med. Bl., 1885, 8, 267.

3. Tuffier, Diabète et néoplasmes. Arch. gén. de méd., 1888, 2, 129.

4. Trinkler, N., Ueber die diagnostische Verwertung des Gehaltes an Zucker und reducirender Substanz im Blute vom Menschen bei verschiedenen Krankheiten. Zentralbl. f.d. Med. Wissensch., 1890, 28, 498.

5. Rohdenburg, G. L., Bernhard, A., and Krehbiel, O., Sugar tolerance in cancer. J. A. M. A., 1919, 72, 1528.

6. Edwards, S., Blood sugar tolerance in cancer. J. Indiana M. A., 1919, 12, 296.

7. Theis, R. C., and Stone, W. S., A study of the chemical composition of the blood in cancer. J. Cancer Research, 1919, 4, 349. 
8. Williams, J. R., with the collaboration of Humphreys, E. M., Clinical significance of blood sugar in nephritis and other diseases. Arch. Int. Med., 1919, 23, 537.

9. Friedenwald, J., and Grove, G. H., The blood-sugar tolerance test as an aid in the diagnosis of gastrointestinal cancer. Am. J. M. Sc., 1920, 160, 313.

10. Langston, W., Glucose tolerance test. J. Lab. \& Clin. Med., 1922, 7, 293.

11. Kelly, T. C., Blood-sugar retention in carcinoma. Am. J. M. Sc., 1925, 169, 216.

12. Slosse, and Reding, Etudes des altérations humorales dans le cancer et le précancer. Le Cancer, 1927, 4, 442.

13. Jackson, D., Carbohydrate metabolism in cancer. Texas State J. Med., 1929, 24, 622.

14. D'Halluin, M., Cancer, glycémie expérimentale, radiations. Bull. et mém. Soc. de Radiol. méd. de France, 1930, 18, 249.

15. Chatain, A., Contribution à l'étude du métabolisme des cancéreux (métabolisme des corps azotés et des hydrates de carbone, glutathion de sang). J. de méd. de Lyon, 1930, 11, 507.

16. Woodward, G. E., and Fry, E. G., The hyperglycaemia of cancer. Biochem. J., 1932, 26, 889.

17. Andersen, P. E., Variations in the glucose tolerance test curves in patients with endometrial carcinoma. Acta radiol., 1952, 37, 178.

18. Glicksman, A. S., Myers, W. P. L., and Rawson, R. W., Diabetes mellitus and carbohydrate metabolism in patients with cancer. M. Clin. North America, 1956, 40, 887.

19. Nelson, N., A photometric adaptation of the Somogyi method for the determination of glucose. J. Biol. Chem., 1944, 153, 375.

20. Somogyi, M., A new reagent for the determination of sugars. J. Biol. Chem., 1945, 160, 61.

21. Taussky, H. H., and Shorr, E., A microcolorimetric method for the determination of inorganic phosphorus. J. Biol. Chem., 1953, 202, 675.

22. Conard, V., Franckson, J. R. M., Bastenie, P. A., Kestens, J., and Kovacs, L., Etude critique du triangle d'hyperglycémie intraveineux chez l'homme normal et détermination d'un "coefficient d'assimilation glucidique." Arch. internat. de pharmacodyn. et de therap., 1953, 93, 277.

23. Amatuzio, D. S., Stutzman, F. L., Vanderbilt, M. J., and Nesbitt, S., Interpretation of the rapid intravenous glucose tolerance test in normal individuals and in mild diabetes mellitus. J. Clin. Invest., 1953, 32, 428.

24. Duncan, L. J. P., The intravenous glucose tolerance test. Quart. J. Exper. Physiol., 1956, 41, 85.

25. Greville, G. D., The intravenous glucose tolerance equation. Biochem. J., 1943, 37, 17.
26. Lozner, E. L., Winkler, A. W., Taylor, F. H. L., and Peters, J. P., The intravenous glucose tolerance test. J. Clin. Invest., 1941, $20,507$.

27. Jokipii, S. G., and Turpeinen, O., Kinetics of elimination of glucose from the blood during and after a continuous intravenous injection. J. Clin. Invest., 1954, 33, 452.

28. Shreeve, W. W., Baker, N., Miller, M., Shipley, R. A., Incefy, G. E., and Craig, J. W., $\mathrm{C}^{14}$ studies in carbohydrate metabolism. II. The oxidation of glucose in diabetic human subjects. Metabolism, 1956, 5, 22.

29. Dominguez, R., Kinetics of elimination, absorption and volume of distribution in the organism in Medical Physics, O. Glasser, Ed., Chicago, The Year Book Publishers, Inc., 1950, Vol. 2, p. 476.

30. Conard, V., Mesure de l'assimilation du glucose. Thesis, Brussels, Acta Medica Belgica, 1955, p. 54.

31. Wertheim, A. R., Eurman, G. H., and Kalinsky, H. J., Changes in serum in organic phosphorus during intravenous glucose tolerance tests: In patients with primary (essential) hypertension, other disease states, and in normal man. J. Clin. Invest., 1954, 33, 565.

32. Lazarus, S. S., Volk, B. W., Jacobi, M. J., and Gilady, M. Y., Absolute lymphocyte count and serum inorganic phosphorus after glucose administration in diabetic patients. Am. J. Clin. Path., 1952, 22, 127.

33. Pollack, H., Millet, R. F., Essex, H. E., Mann, F. C., and Bollman, J. L., Serum phosphate changes induced by injections of glucose into dogs under various conditions. Am. J. Physiol., 1934, 110, 117.

34. Harrop, G. A., Jr., and Benedict, E. M., The participation of inorganic substances in carbohydrate metabolism. J. Biol. Chem., 1924, 59, 683.

35. Groen, J., Willebrands, A. F., Kamminga, C. E., Van Schothorst, H. K., and Godfried, E. G., Effects of glucose administration on the potassium and inorganic phosphate content of the blood serum and the electrocardiogram in normal individuals, and in non-diabetic patients. Acta med. Scandinav., 1952, 141, 352.

36. Cori, C. F., and Cori, G. T., The carbohydrate metabolism of tumors. II. Changes in the sugar, lactic acid, and $\mathrm{CO}_{2}$-combining power of blood passing through a tumor. J. Biol. Chem., 1925, 65, 397.

37. Greenstein, J. P., Biochemistry of Cancer. 2nd ed., New York, Academic Press, Inc., 1954, p. 507.

38. Weber, G., and Cantero, A., Glucose-6-phosphatase activity in normal, precancerous and neoplastic tissues. Cancer Research, 1955, 15, 105.

39. Joslin, E. P., Root, H. F., White, P., and Marble, A., The Treatment of Diabetes Mellitus. 9th ed., Philadelphia, Lea \& Febiger, 1952, p. 564. 